\title{
Hypoxic Incubation Leads to Concerted Changes of Carbonic Anhydrase Activity and 2.3 DPG Concentration of Chick Embryo Red Cells ${ }^{1,2}$
}

\author{
Rosemarie Baumann, E. A. Haller, U. Schöning, and M. Weber \\ Zentrum Physiologie Medizinische Hochschule, e000 Hannover 61, Federal Republic of Germany
}

Received August 6, 1985; accepted in revised form January 29, 1986

\begin{abstract}
Red cell carbonic anhydrase activity, 2.3 DPG concentration, and activities of three key enzymes controlling DPG metabolism (PK, PFK and DPGM) were measured in normoxic and hypoxic (incubation in $13.5 \% \mathrm{O}_{2}$ ) chick embroys. In normoxia 2.3 DPG concentration and carbonic anhydrase activity begin to increase by the third week of incubation. Hypoxia induces a rise of $2.3 \mathrm{DPG}$ concentration and carbonic anhydrase activity by Day 8 of development, i.e., 1 week earlier. Since during normal development chick embryos become hypoxic in the third week of incubation, the results suggest that $\mathrm{PO}_{2}$ has a controlling influence on the timing of differentiation events of definitive embryonic red cells. (c) 1986 Academic Press, Inc.
\end{abstract}

\section{INTRODUCTION}

Embryonic erythrocytes offer a good model for the study of cellular differentiation during ontogeny. For the chick embryo extensive documentation exists on several aspects of red cell metabolism and structure during the process of maturation of the primitive and the consecutive definitive red cell population (cf. Romanoff, 1969; Bruns and Ingram, 1973; Chan, 1981).

Virtually nothing is known about the processes that control the timing of the differentiation events in embryonic erythrocytes. We have recently found that the switch from embryonic to adult hemoglobin is influenced by environmental oxygen pressure in such a way that definitive erythrocytes, which carry the adult hemoglobins, appear precociously in the blood of hypoxic embryo (Baumann et al., 1983), but appear later than normal in hyperoxic embryos (Baumann et al., 1979). Oxygen pressure also influences the phosphate pattern of the embryonic red cells. During normal ontogeny there is a rapid fall of the ATP concentration and a concomitant increase of red cell 2.3 diphosphoglycerate $(2.3 \mathrm{DPG})$ in the last week of incubation (Harkness and Isaacks, 1975). In hypoxia the ATP levels were found to decline much more rapidly than in normoxia (Baumann et al., 1983). On the other hand Ingermann et al. (1983) have shown that, in embryos older than $\mathbf{1 4}$ days, hyperoxia attenuates the normally occurring fall of the ATP concentration and at the same time they observed only a small increase of the 2.3 DPG concentration, which normally increases drastically between 14 and 16 days of development. These findings support the idea that the changes

\footnotetext{
${ }^{1}$ Dedicated to Professor H. Bartels on the occasion of his 65 th birthday.

${ }^{2}$ Supported by DFG SFB 146.
}

of red cell organic phosphate pattern found in late development are stimulated through the fall in $\mathrm{PO}_{2}$ of the chorioallantoic veins (Tazawa, 1980).

As a result of the changes in phosphate pattern blood oxygen affinity increases (Misson and Freemann, 1972; Bartels et al., 1966) helping the embryo to maintain adequate oxygenation despite lowered blood $\mathrm{PO}_{2}$. However, it is not clear if the oxygen pressure affects only the phosphate pattern or if it influences the differentiation of the embryonic red cell in a broader sense. One specific marker for late fetal red cells is carbonic anhydrase, which is initially low but increases continuously during late development. In human fetal blood carbonic anhydrase is coordinately expressed with adult hemoglobin (Boyer et al., 1983). In the chick embryo carbonic anhydrase activity of erythrocytes has been determined by Clark (1951), who was unable to detect activity in embryos of less than 12 days of age. From his experiments one had to conclude that carbonic anhydrase is not expressed by the primitive red cells that constitute the first red cell population up to Day 6 of development nor by the first populations of definitive erythrocytes, which because of their short life span have disappeared almost completely by Day 14 (Lemez, 1977).

We have measured the activity of carbonic anhydrase and the concentration of $2.3 \mathrm{DPG}$ in red cells from chronically hypoxic and normoxic embryos. The findings suggest that hypoxia affects fundamental control mechanisms of definitive erythrocyte differentiation during ontogeny.

\section{MATERIALS AND METHODS}

Fertilized eggs from white Leghorn chicken were incubated at $37.5^{\circ} \mathrm{C}$ either in air or $13.5 \%$ oxygen. Blood 
was taken between Days 4 and 18 from extraembryonic blood vessels, washed repeatedly in buffer $(0.05 \mathrm{~mole} /$ liter Tris, $\mathrm{pH} 7.5$, at $20^{\circ} \mathrm{C}, 138 \mathrm{mmole} \mathrm{NaCl}, 5$ mmole/ liter glucose; osmolarity 280 mosmole/liter) and filtered through microcrystalline cellulose- $\alpha$-cellulose before determination of enzyme activities. Packed red cells were either processed immediately or stored in liquid nitrogen. Carbonic anhydrase activity was measured at $0^{\circ} \mathrm{C}$ using the method of Maren (1960) as modified by Bruns et al. (1986). Activities are given as units/milliliter red blood cell.

Diphosphoglycerate mutase (DPGM) activity was measured following the assay of Schröter and Kalinowsky (1969), pyruvate kinase (PK) activity and phosphofructokinase (PFK) activity were determined as described by Beutler (1972). The activities were measured at $340 \mathrm{~nm}$ and $37^{\circ} \mathrm{C}$ using a Hitachi Model $150-20$ spectrophotometer. Activities are expressed as IU/g Hb. Hemoglobin was determined as cyanmethemoglobin, 2.3 DPG concentrations were determined with a test-kit. Between 3 and 10 determinations were made for each day and group. All reagents were purchased from Boehringer $\mathrm{Co}$. Mannheim. Mean values were compared for significant differences using Student's $t$ test for unpaired samples.

\section{RESULTS AND DISCUSSION}

Figure 1 shows the carbonic anhydrase activity for air incubated embryos between 4 and 18 days of development and hypoxic embryos between 4 and 16 days of development. Unlike Clark (1951) we find that carbonic anhydrase is present throughout the investigated interval. This can probably be attributed to the greater sensitivity of the Maren-method for measurement of carbonic anhydrase activities in small samples, compared to the one used by Clark (1951). The primitive red cells that constitute the only red cell population up to Day 6 , have a higher activity than the subsequently produced definitive red cells.

Within the primitive red cell population activity declines from 2090 units $/ \mathrm{ml}$ red cell at Day 4 to 686 units at Day 6. Note that the carbonic anhydrase activity of primitive red cells from hypoxic embryos is not significantly different between 4 and 6 days of development. In normoxic embryos the minimum activity is found in 8- to 12 -day-old embryos with about 300 units $/ \mathrm{ml} \mathrm{RBC}$. From Day 14 onward there is a sharp rise of carbonic anhydrase activity up to 14,000 units $/ \mathrm{ml}$ red cell at Day 18. A rise of quantitatively similar proportions has also been described by Clarke (1951).

In hypoxia carbonic anhydrase activity is already significantly increased at Day 8 of incubation. At this time hypoxic embryos have carbonic anhydrase activities similar to those found at Day 14 in normoxic embryos.

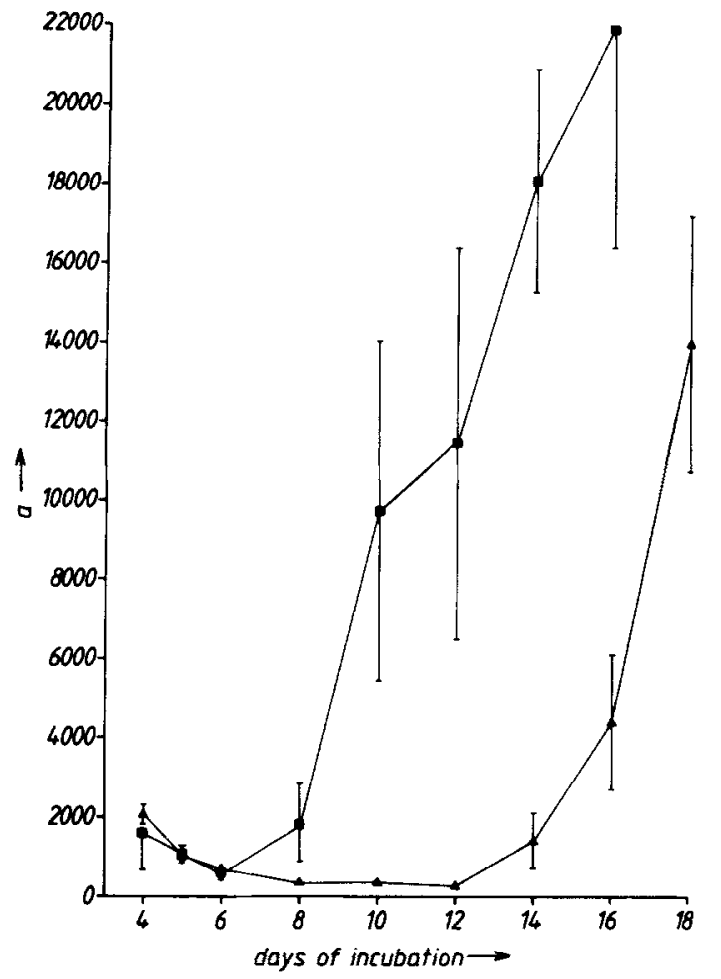

Fig. 1. Mean values and standard deviation of carbonic anhydrase activity a (units $/ \mathrm{ml}$ red cells) for normoxic ( $\boldsymbol{\Lambda})$ and hypoxic ( $\square$ ) chick embryos.

Between 8 and 12 days activity increases from 1845 to 11,500 units, which is comparable to the increase found in normoxic embryos between Days 14 and 18 (from 1440 units to 14,090 units). Thus the timing of the transition from low to high carbonic anhydrase activities is shifted by about 1 week in the hypoxic embryos.

Parallel changes occur with respect to the $2.3 \mathrm{DPG}$ concentration of red cells (Fig. 2). While in normoxia the 2.3 DPG concentration is low $(<0.3$ mole $2.3 \mathrm{DPG} /$

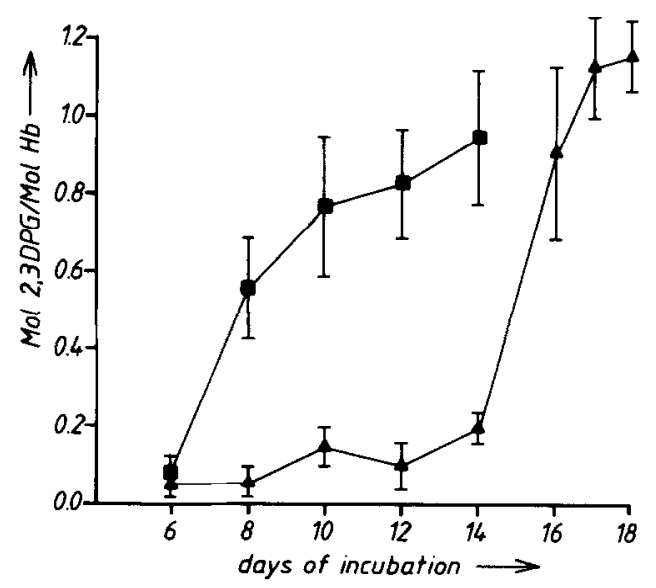

Fig. 2. Mean and standard deviation of 2.3 DPG concentration (mole/

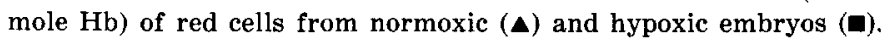
Each point is the mean value of at least 4 determinations. 
mole $\mathrm{Hb}$ ) up to Day 14 , hypoxic embryos have 0.56 mole $\mathrm{DPG} / \mathrm{mole} \mathrm{Hb}$ at Day 8 and 0.8 mole $2.3 \mathrm{DPG} /$ mole $\mathrm{Hb}$ at Day 10. Both in normoxia and hypoxia the increase of $2.3 \mathrm{DPG}$ concentration precedes the surge of carbonic anhydrase activity by about 1 day.

The present results allow several conclusions. In the first place primitive red cells are unaffected by hypoxia since at Day 4 to 6 , when both normoxic and hypoxic embryos have predominantly primitive cells in their circulation, no significant differences for carbonic anhydrase activity are present, and the $2.3 \mathrm{DPG}$ concentration at Day 6 is also the same for hypoxic and normoxic embryos. Second, the increase of the carbonic anhydrase activity and the change in phosphate pattern are apparently not tied to a specific subpopulation of definitive red cells. Lemez (1977) has characterized the morphology of the definitive cells produced by the embryo between 6 days of incubation until hatching and distinguishes three subpopulations that appear sequentially between Days 6 and 14. The first subpopulation has nearly disappeared by Day 14 due to its short life span and dilution through subsequently produced red cells. By morpholgical criteria definitive red cells of 8or 10-day-old hypoxic and normoxic embryos cannot be distinguished, as inspection of blood smears demonstrated. However, it is apparent that the first definitive red cell populations are able to express a program that is normally realized much later in a different subpopulation, provided the necessary stimulus is given. The data are consistent with the idea that the physiological stimulus during ontogeny is the fall of the $\mathrm{PO}_{2}$ of the arterialized chorioallantoic blood, which decreases from about $90 \mathrm{~mm} \mathrm{Hg}$ to about $50 \mathrm{~mm} \mathrm{Hy}$ (Tazawa, 1980), and we calculated a similarly low $\mathrm{PO}_{2}$ value for the blood of embryos incubated in $13.5 \%$ oxygen (Baumann et al., 1983).
Finally we have tried to determine if changes of the activities of the key enzymes controlling 2.3 DPG concentration are responsible for the difference between hypoxic and normoxic embryos since this is the mechanism by which the 2.3 DPG concentration of mammalian fetal red cells is adjusted (Jelkmann and Bauer, 1981). Table 1 gives the activities for pyruvate kinase (PK), phosphofruktokinase (PFK), and 2.3 diphosphoglyceratemutase (DPGM). The PFK activities remain nearly constant throughout the investigated interval: the PK activities found in hypoxic blood tend to be higher, which would favour a lowering of the 2.3 DPG concentration (Jelkmann and Bauer, 1981). The activity for DPGM increases between Days 10 and 16 in both groups. A comparison of normoxic and hypoxic embryos shows, however, that there is no clear correlation between DPGM activity and 2.3 DPG. These results suggest that the control mechanisms for the change in 2.3 DPG concentration (as well as the concomitant fall of ATP) are localized elsewhere and probably tied to more fundamental alterations of the red cell metabolism. That DPGM activity and 2.3 DPG concentration are not correlated was also observed by Harness et al. (1977), who found considerable DPGM activity but only trace amounts of 2.3 DPG in red cells of day-old chickens.

\section{REFERENCES}

Bartels, H., Hiller, G., and Reinhardt, W. (1966). Oxygen affinity of chicken blood before and after hatching. Respir. Physiol. 1, 345356.

BaumanN, R., and LUdders, S. I. (1979). Different developmental changes of the hemoglobin pattern in normoxic and hyperoxic chicken embryos. Pflügers Arch. 379(S), R24.

Baumann, R., Padeken, S., Haller, E. A., and Brilmayer, TH. (1983). Effects of hypoxia on oxygen affinity, hemoglobin pattern, and blood volume of early chicken embryos. Am. J. Physiol. 244, R733-R741.

TABLE 1

Mean Values $(\bar{x})$, Standard Deviation (SD), and Sample Size $(n)$ of Determinations of DPGM, PK, and PFK ACtivity (IU/gHb) of Red Blood Cells from Normoxic and Hypoxic Embryos ${ }^{a}$

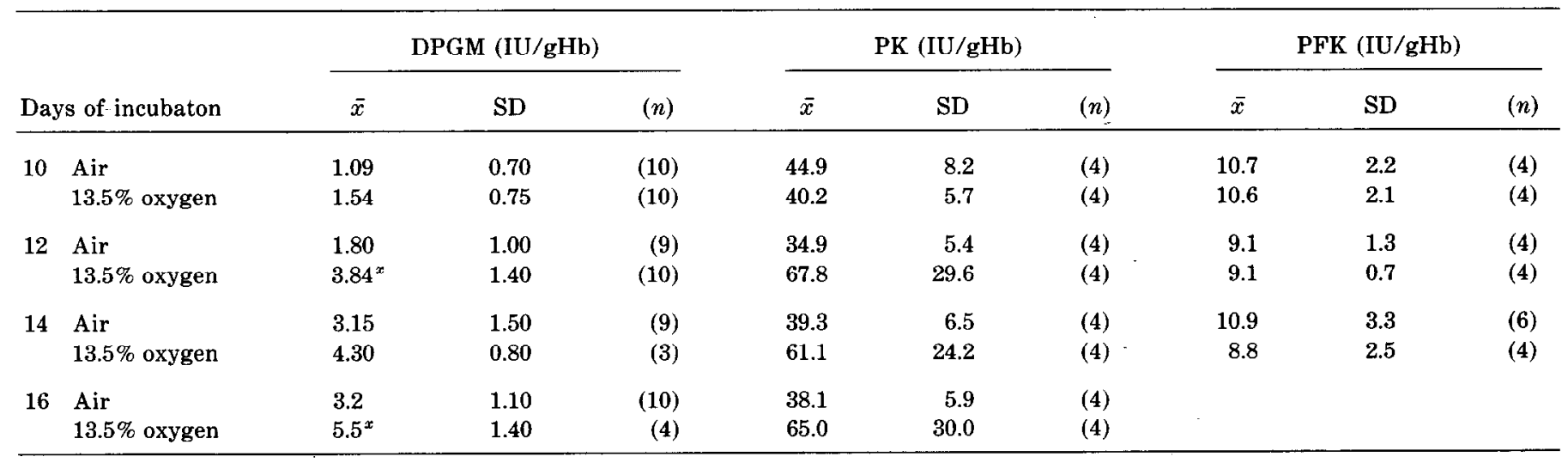

${ }^{a} T=37^{\circ} \mathrm{C}, \mathrm{pH}=7.8 ; x$ indicates significant difference. 
BeutLer, E. (1975). "Red Cell Metabolism," 2nd ed. Grune \& Stratton, New York.

Boyer, S. H., Siegel, S., and Noyes, A. M. (1983). Developmental changes in human erythrocyte carbonic anhydrase levels: Coordinate Expression with adult hemoglobin. Dev. Biol. 97, 250-253.

BRUNS, W., DERMIETZEL, R., and GROS, G. (1986). Carbonic anhydrase in the sarcoplasmatic reticulum of rabbit skeletal muscle. J. Physiol 371, 351-364.

BRuns, G. A. O., and Ingram, V. M. (1973). The erythroid cell and hemoglobins of the chick embryo. Philos. Trans. $R$. Soc London 266 , 255-305.

CHAN, L. N. L. (1981). Changes in red cell membrane during differentiation. In "Hemoglobins in development and differentiation" (G. Stamatoyannopoulos and A. W. Nienhuis, Eds.), pp. 407-422. Liss, New York.

ClaRK, A. M. (1951). Carbonic anhydrase activity during embryonic development. J. Exp. Biol. 28, 332-343.

HARKNESS, D. R., and ISAACKS, R. E. (1975). 2.3-Diphosphoglycerate in erythrocytes of chick embryos. Science 189, 393-394.

Harkness, D. R., Isaacks, R. E., and Roth, S. C. (1977). Purification and properties of 2.3-Bisphosphoglycerate phosphatemutase from erythrocytes of day-old chicks. Eur. J. Biochem. 78, 343-351.
IngermanN, R. L., Stock, M. K., Metcalfe, J., and ShI, T. B. (1983). Effect of ambient oxygen on organic phosphate concentrations in erythrocytes of the chick embryo. Respir. Physiol 51, 141-152.

JelkmanN, W., and BaUER, C. (1981). Regulation of red cell DPG metabolism in fetuses and adults. Acta. Biol. Med. Germ. 40, 661-664.

Lemez, L. (1977). Quantitative Studie der fünf Typen der definitiven Erythrozyten (E II) beim Hühnerembryo. Verh. Anat. Ges. 71, 235238.

MAREN, TH. H. (1960). A simplified micromethod for the determination of carhonic anhydrase and its inhihitiors. J. Pharm. Exp. Therapeut. 130, 26-29.

Misson, B. H., and Freeman, B. M. (1972). Organic phosphates and oxygen affinity of chick blood before and after hatching. Respir. Physiol. 14, 343-352.

Romanoff, A. L. (1967). "Biochemistry of the Avian Embryo." Wiley, New York.

SCHRÖTER, W., and KALINOWSKY, W. (1969). Erythrocyte 2.3 diphosphoglycerate mutase: An optical test in hemolysates. Clin. Chim. Act. 25, 283-285.

TAZAWA, H. (1980). Oxygen and $\mathrm{CO}_{2}$ exchange and acid-base regulation in the avian embryo. Amer. Zool. 20, 295-404. 